\title{
Expanding animosity typology as antecedent consumer ethnocentrism toward purchase intentions of foreign products
}

\author{
Ramadania \\ Faculty of Economics and Business \\ Universitas Tanjungpura, Indonesia
}

\author{
Keywords \\ Animosity, Consumer Ethnocentrism, Purchase Intention, Foreign Products
}

\begin{abstract}
Animosity and Consumer Ethnocentrism is a concept of psychological-social which describes the negative attitude in evaluating foreign products. The aim of this study is to provide empirical facts of the expansion of the four-typology animosity as an antecedent of consumer ethnocentrism (CE). In addition, this study aims to test CE as a predictor of foreign products purchase intention in developing countries. namely Indonesia. This study uses survey method. The research sample are 225 respondents from Indonesia. The product categories are supplement foods from the United States. The results show that the national stable animosity. personal stable animosity and personal situational animosity are antecedent of CE. Meanwhile, national situational animosity is not proven to have an influence on CE. This study also proves that CE has a negative influence on foreign products purchase intention.
\end{abstract}

Corresponding author: Ramadania

Email addresses for corresponding author: ramadhania@ekonomi.untan.ac.id

First submission received: $26^{\text {th }}$ February 2018

Revised submission received: $20^{\text {th }}$ August 2018

Accepted: $25^{\text {th }}$ September 2018

\section{Introduction}

Animosity and Consumer Ethnocentrism (CE) are negative attitudes in evaluating foreign products (Klein and Ettention, 1998, 1999). The marketing literature describes animosity and ethnocentrism as the concepts that have implications for psychological and behavioral reactions to a particular country of origin. (Nisjssen and Douglas, 2004; Jimenez and Martin, 2010; Klein et al., 1998) argues that animosity, as well as CE influence consumer's purchase intention, which ignores product judgment. Negotiable emotions such as animosity and CE can cause rejection of foreign products. Animosity is different from ethnocentrism. Ethnocentrism concerns beliefs about foreign products in general. While animosity is directed to certain countries (Klein, 2002; Klein et al. 1998; Klein and Ettenson, 1999). Thus, the consumer's animosity is considered capable to explain the consumer's negative attitudes toward products from certain countries and consumers are reluctant to buy products from the concerned country. (Rose et al., 2009).

Previous studies have found that animosity have negatively affects toward attitudes of foreign products (Klein et al., 1998, 1999, 2002; Russel and Russel 2006; Nakos and Hadijimitriou, 2007; Rose et al., 2009; Ramadania et al., 2013). Other studies have found that animosity may decrease the willingness and intention to purchase foreign products (Klein et al., 1998, 1999, 2005; Nisjeen and Douglas, 2004; Torres and Gutieres, 2007; Bahaee and Pisani, 2009; Maher 2010; Lee and Tae Lee, 2013). Recent studies also showed that CE may affect negative attitudes toward foreign products (Sharma et al., 1995; Javalgy et al., 2005; Bahaee and Pisani, 2009; Ramadania et al., 2015). Then the CE will have an impact in decreasing the desire and intention to purchase foreign products (Rose et al., 2009; Nakos and Hadijimitiou, 2007; Torres and Gutieres, 2007; Jun \& Ma. 2012; Spillan and Harcar., 2012; Giang and Dinh, 2015 ).

Klein et al., $(1998 ; 1999)$ stated that animosity and CE may be interconnected. Although (Klein et al., 1998;1999) recognized both of them are interconnected. but they do not provide the fact that there is a relationship between these two variables. The opinions and findings of (Klein et al., 1998;1999) are supported by the findings of Rose et al. (2009), which showed that animosity and CE have an effect on the 
reluctance to purchase foreign products. Animosity and CE are interconnected but it is not known clearly for the position of the relationship between both of them. According to Klein et al., 1998. CE and animosity can arise due to political and economic events that may affect consumer attitudes toward imported products. Nakos and Hadijimitrou (2007), stated that if a person has a strong negative view on foreign countries. it is very likely that this view will affect his/her buying behavior. Nisjenn and Douglas (2004) stated that hostile out-group can increase ethnocentrism behavior. Therefore, it can be said that there is a chain of relationship between moral and social norms and consumer behavior, when a person emphasizes animosity in increasing consumer emotional on the country of origin of a product (Balabanis et al., 2002; Shimp and Sharma 1987; Jimenez and Martin. 2010). This is supported by the findings of Ang et al., (2004).

The original animosity model (Klein et al., 1998) did not put animosity as the antecedent of CE. Similarly, the CE theory proposed by Shimp and Sharma (1987) also did not put animosity as the predictor of CE. In general, most of the studies conducted on CE also lacked of consideration on the importance of animosity variable as the predictor in CE models they built (Ranjbbarian et al., 2010; Watson and Wright, 2000; Javalgi et al., 2005; Moon and Jain, 2002; Kwak et al., 2006; Hsu and Nien., 2008; Nguyen et al., 2008; Ruyter et al.. 1998). Recently, few studies that replicated the study conducted by Klein et al., (1998), for example Nakos and Hajidimitrou (2007) and Rose et al. (2009) Russel and Russell (2006), Bahaee and Pisani (2009) seemed to incorporate animosity variable into the CE model but did not put animosity as the predictor of CE. In line with that thought, Shankarmahesh (2006) suggested for future study to examine animosity as the predictor of CE. This opinion is supported by several recent findings that found that animosity has a positive effect on CE, including Nisjenn and Douglas (2004), Torres and Gutieres (2007) and Jimenez and Martin (2010). However, these studies still used the measurement of war animosity and economic animosity as proposed by Klein $(1998,1999,2001$ \& 2002).

Some previous studies (Jung et al., 2002; Ang et al., 2004; Hamim and Elliot, 2006; Lwim et al., 2010; Sutikno and Cheng, 2011) provided a fact that, Indonesian people have relatively high levels of CE and animosity towards America. However, these studies did not put animosity as the antecedent of CE. Negative attitudes can have an effect on the rejection of products from the concerned country (Amine, 2008; Bahaee and Pisani, 2009). Some of these studies (Jung et al., 2002; Ang et al., 2004; Hamim and Elliot. 2006; Lwim et al., 2010) did not examine CE in Indonesia on the supplement foods product category. Currently, the largest imported supplement foods are from America. These supplement foods consist of traditional medicines and herbs for health. The market share of the American traditional and herbal medicines in Indonesia reached $47 \%$ of the total import. Based on data from the Ministry of Trade, the value of imports of traditional and herbal medicines throughout 2011 reached US\$ 40.48 million. From this amount, the US products were recorded reaching US\$ 19.13 million. (http://industri.bisnis.com. 2011). Therefore, this study had several purposes. as follows; first. to test the animosity as the antecedent of CE that has not been revealed by Klein (1998). Second, the measurements used by Klein (1998, 1999, 2001 \& 2002) in measuring animosity were based on war and economic animosity. This study is different from that of Klein $(1998,1999,2001$ \& 2002). This study will develop four tipologies of animosity based on the concept of Ang et al., (2004) and Jung et al., (2002) as the antecedent of CE. The four typologies of animosity are national stable animosity, personal stable animosity, national situational animosity and personal situational animosity (Ang et al., 2004 \& Jung et al.. 2002). Third. this study examined the CE in predicting the purchase intention of foreign products of the consumers in a developing country. namely Indonesia. Some previous studies, such as Klein $(1998,1999,2001$ \& 2002) and other studies examined animosity and CE of consumers in developed countries. Rejection towards foreign products is possible because domestic products are relatively good. It is in contrast to developing countries, as the domestic products have a relatively lower quality compared to those of developed countries in general. This study contributes to the testing of animosity and CE in a developing country, namely Indonesia.

\section{Literature Review}

\section{Consumer Ethnocentrism dan Animosity}

Consumer ethnocentrism is essentially derived from the concept of ethnocentrism (Shimp and Sharma, 1987). This concept states that consumers have a "tendency" rather than an "attitude". which is commonly used in referring consumer feeling to a particular object. (Shimp and Sharma, 1987; Sharma et 
al., 1995). Shimp and Sharma (1987) defined CE as consumer confidence "about the appropriateness, or morality of foreign product purchase ... [which gives the individuals] ... sense of identity, sense of belonging, and most importantly, whether the buying behavior is acceptable or unacceptable to the group he/she belongs to".

Intra-personal conflict theory views "in-group favoritism Vs Out-group prejudice" (Haitem et al., 2010). This theory implies that a person always sees what is good or not in the group and looks at what is in the other group with prejudice or the "in-group love and out-group hate." (Sumner's 1906; Haitem et $a l, .2010)$. That is to love something that belongs to the group he/she belongs to and to hate something that belongs to another group. Ethnocentric consumers assume that buying foreign products is unpatriotic, and they will tend to consider and select local products. (Shimp and Sharma, 1987 ; Shankarmahesh, 2006; Liu et al., 2006). The nationalism will affect consumers in purchasing local products and reject foreign products. Klein et al. (1998) defined animosity as "a remnant of antipathy related to something that happened previously (in the past), or sustainable military, political or economic events". Consumer animosity describes negative emotional or antipathic attitudes toward a particular country or group (Klein and Ettension, 1998, 1999 \& 2002). Emotion can not be separated from the outcome of the ongoing territorial disputes, economic events, Diplomatic disagreements and/or religious conflicts (Riefler and Diamandtopoulos, 2007). Klein et al. (1998) distinguished animosity based on war and economic animosity. However, Jung et al., (2002) and Ang et al., (2004) distinguished the types of animosity into personal animosity Vs national animosity and stable animosity vs situational animosity. The construct of consumer animosity is placed ahead by Klein et al. (1998), as a country of origin phenomenon that results in differences derived from past studies and cannot be explained by consumer ethnocentrism.

\section{Typologies of Animosity as the antecedent of Consumer Ethnocentrism}

Animosity and CE are the concepts associated with the country of origin of a product (Jimenez and Martin, 2010). Klein (1998) stated that animosity is different from CE. However, Klein et al. (1998) recognized that these two constructs are interconnected. This opinion is supported by the findings of Rose et al., (2009), which showed that animosity and CE have an effect on the reluctance to purchase foreign products. Animosity and CE are interconnected, but it is not clearly known for the position of the relationship between both of them. Nisjenn and Douglas (2004) suggested that hostile out-group increases ethnocentric behavior. Shankarmahesh (2006) suggested for future study to examine animosity as the antecedent of CE. "The existence of a chain of relationship between moral and social norms and consumer behavior, when consumer emphasizes animosity, will add an emotional level of consumer on the country of origin of a product." (Balabanis et al., 2002; Shimp and Sharma, 1987; Jimenez and Martin, 2010).

In the context of Indonesia as a developing country, there are at least four studies related to ethnocentrism and/or animosity. They are Jung et al., (2002). Ang et al., (2004) Hamim and Elliot (2006) and Lwim et al., (2010). The studies conducted by Jung et al., (2002) and Ang et al., (2004), which had conducted surveys in five countries in Asia (Indonesia, Malaysia, Singapore, Korea and Thailand), were aimed to validate the typologies of animosity using the targeted American and Japanese entities. The results of study conducted by Jung et al., (2002) suggested that four typological structures factors (personal Vs national animosity and situational vs stable animosity), could be proven. This study found that Indonesia has the greater situational animosity towards America than Japan. The findings are supported by Ang et al., (2004), which showed the Indonesian people have the highest personal situational animosity compared to other Asian countries in fighting against America regarding the condition of economic problems occurred in Indonesia. In addition. Ang et al., (2004) found that Indonesia has the highest ethnocentrism level against American and Japanese products compared to other Asian countries (Malaysia. Singapore, Thailand and Korea). The findings are supported by Hamim and Elliot (2006) who found that the CE of Indonesian society is high. The study conducted by Hamim and Elliot (2006) also showed that there is a relationship between CE and purchase intention both on physical goods and services. Meanwhile, Lwin et al., (2010) who conducted a study on seventeen countries found high animosity towards America. From these studies (Jung et al., 2002; Ang et al. ,2004; Hamim and Elliot. 2006; Lwim et al., 2010) it was informed that in general Indonesian people have a relatively high level of CE and 
animosity towards America. The study conducted by Sutikno and Cheng (2011) showed that the United States of America is a country that has the highest score of animosity from the Indonesian people.

Some recent studies have found that animosity has a positive effect on CE (Nisjenn and Douglas, 2004; Torres and Gutieres, 2007; Jimenez and Martin, 2010). At the time of economic crisis in Asia, the negative feeling in the form of consumer animosity towards America/Japan increased. When animosity is activated, it will simultaneously bring out a latent consumer ethnocentrism (Ang et al., 2004). According to (Klein et al., 1998; Klein, 2002; Nijssen and Douglas 2004), in addition to war and economic animosity, there are a number of sources of animosity found in the literatures, such as ecological animosity, policy animosity and socio-cultural animosity. Klein et al., (1998) distinguished animosity based on the war and economic animosity. Meanwhile, Jung et al. (2002) and Ang et al. (2004) distinguished the types of animosity into four. They are; personal animosity vs national animosity and stable animosity vs situational animosity. The type of animosity is divided by 1) National stable animosity, 2) National situational animosity, 3) personal stable animosity, and 4) personal situational animosity. According to Ang et al., (2004) stable animosity shows negative feelings arising from general historical backgrounds, such as military or economic problems that occurred previously between two countries. Situational animosity shows negative feelings associated with certain circumstances. Animosity can also be differentiated on a personal or national level. "Animosity at the national level indicates a macro level, that is the animosity of a country based on the perception of how a foreign country treats this country. At a micro level. animosity is based on personal negative experience of a foreign country or people of the concerned country, (Ang et al.. 2004).

\section{National Stable Animosity and CE}

Riefler and Diamantopoulos (2007) stated that National stable animosity comes from a general historical background. Unequal treatment from foreign countries against our country in the past may cause sentiment at the macro level (Ang et al., 2004). Hence, animosity towards other countries caused by historical events in the past can increase the love of people to their own country. Therefore, the first hypothesis in this study is:

H1: National Stable Animosity has a positive effect on CE

\section{Personal Stable Animosity and CE}

Riefler and Diamantopoulos (2017) stated that personal stable animosity is a General negative feeling due to personal experience. Therefore, it can cause anger towards foreign countries (Ang et al. 2004). Animosity caused by the general negative feelings that a person feels toward the treatment of people from a foreign country can increase consumer's love towards domestic products.

H2: Personal Stable Animosity has a positive effect on CE

\section{National Situational Animosity and CE}

National situational animosity arises temporarily caused by specific, (Riefler and Diamantopoulos (2007). This sentiment arises against foreign countries from macro issues rather than personal perspectives. For example, the economic crisis caused by foreign countries can cause animosity (Ang et al. 2004). Therefore, national situational animosity may cause rejection of products from foreign countries and may increase consumer ethnosentrim against domestic products.

H3: National situational Animosity has a positive effect on CE

\section{Personal Situational Animosity and CE}

Personal situational animosity is a temporary negative sentiment caused by specific circumstance, Riefler and Diamantopoulos (2007), such as anger at a foreign country that causes an economic crisis that creates unemployment for close friends and family can result in animosity towards the concerned foreign country. Ang et al., 2004). Thus, has an impact on the rejection of foreign products and increases consumer love and ethnocentrism.

H4: Personal Situational Animosity has a positive effect on CE

\section{Consumer Ethnocentrism and Purchase Intention}

Shimp and Sharma (1987) who conducted an approach of ethnocentrism in the consumers' perspective depicting ethnocentrism as a belief developed in the process of purchasing foreign products. The main impact of $\mathrm{CE}$ is to direct consumers on the purchase of domestic products as opposed to the 
purchase of foreign products (Shankarmahesh, 2006). Several studies have found that CE has a positive effect on consumer confidence to purchase domestic products (Ranjbbarian et al., 2010 and Vida et al., 2008), the intention or willingness to buy local products (Nguyen et al., 2008 and Jun and Ma. 2012). In contrast, the study conducted by Jun \& Ma (2012) found that CE has a negative effect on the evaluation and willingness to buy against foreign products from Japan and USA. Spillan and Harcar (2012) stated that, in general ethnocentric consumers do not intend to buy goods made in foreign countries, because they think it's dangerous for the domestic economy. The effect of CE has been shown to lead to a decrease in the willingness and intention to buy foreign products (Rose et al., 2009; Nakos and Hadijimitiou, 2007; Torres and Gutieres, 2007), on the decision towards imported products (Nguyen et al.. 2008). Other researchers found that ethnocentrism has been proven to have a strong effect on domestic brand preferences, (Hsu and Nien. 2008; Evanscitzky et al., 2008) and foreign product preferences (Evansckitzky et al., 2008).

H5: CE has a negative effect on the purchase intention of foreign products.

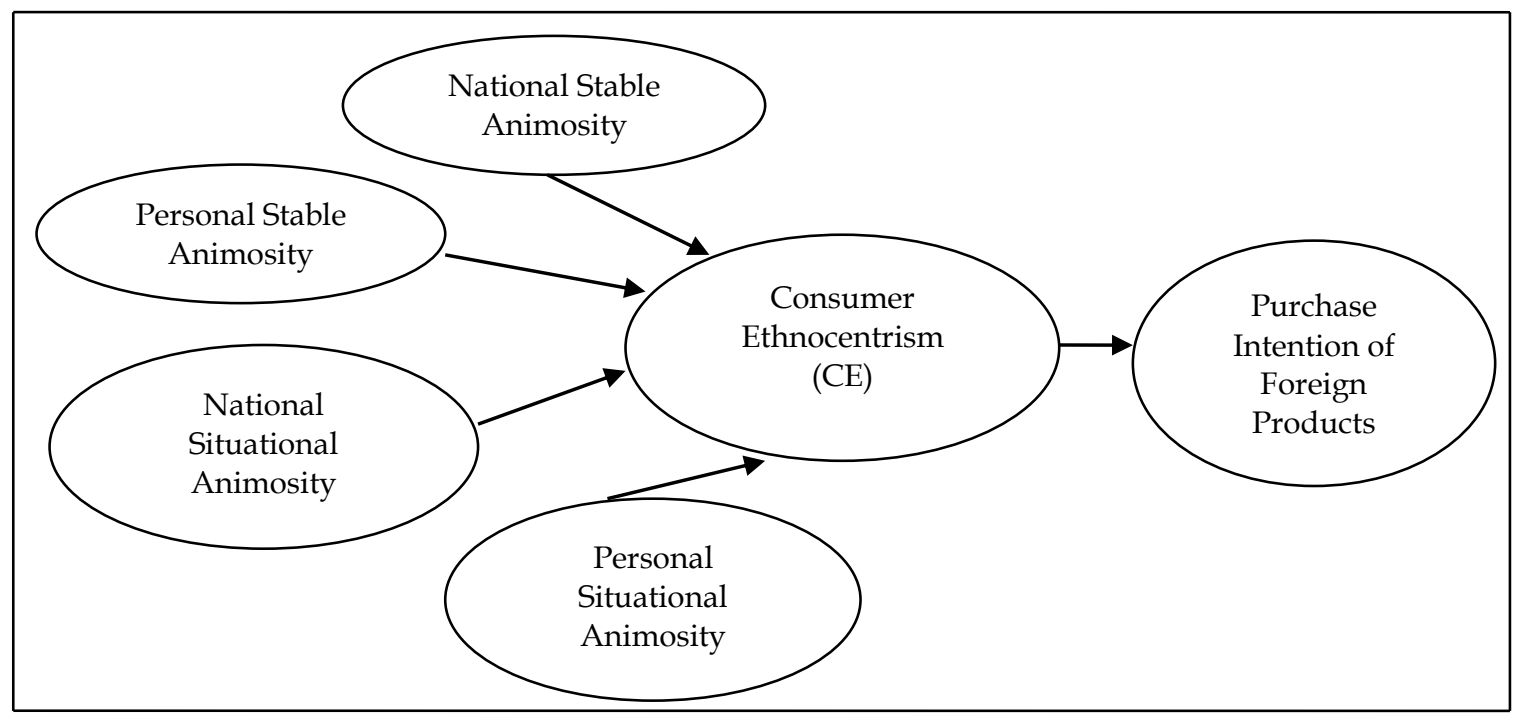

Figure 1. Conseptual Framework

\section{Research Method and Measures}

This study was conducted on 225 consumers in West Kalimantan, Indonesia. The product category included supplement foods from America. The data were collected using questionnaires with accidental methods. The questionnaires were distributed in shopping and community centers. The data were analyzed using Structural Equation Modeling (SEM). The construct of animosity based on the concept of Jung et al., (2002) and Ang et al., (2004) that divided animosity into; national stable animosity, personal stable animosity, national situational animosity and personal situational animosity. Meanwhile, CE was measured by 5 items (Shimp \& Sharma. 1987; and Klein et al., 1998; Ramadania et al., 2015). The construct measurement used a Likert scale of 1-5. Purchase intention was measured by using two items (Edell and Staelin, 1983; Mackenzie et al., 1986; Liu et al., 2006). Furthermore, the measurement items of constructs can be seen in Table 1.

Table 1. Measurement of Constructs

\begin{tabular}{|c|c|c|}
\hline \multirow{2}{*}{\multicolumn{3}{|c|}{$\begin{array}{l}\text { Items of Construct } \\
\text { National Stable Animosity }\end{array}$}} \\
\hline & Stable Animosity & \multirow{4}{*}{ Jung et al., (2002); Ang et al.(2004) } \\
\hline 1) & America does not have consistent attitudes & \\
\hline 2) & America has never been fair towards our country. & \\
\hline 3) & America is a friend of our country only in pleasant condition & \\
\hline \multicolumn{3}{|c|}{ Personal Stable Animosity } \\
\hline 1) & I do not like American people. & \multirow{3}{*}{ Jung et al., (2002); Ang et al.(2004) } \\
\hline 2) & I am angry to American people. & \\
\hline 3) & I will never make friends with American people. & \\
\hline
\end{tabular}


National Situational Animosity

1) It is disappointing that America is making a little effort to solve the

Jung et al., (2002); Ang et al.(2004) political problems with my country.

2) America does not care to my country which has unsafe condition.

3) America wants to take control of my country

Personal Situational Animosity

1) I feel that the mess caused by America has resulted in discomfort to my Jung et al., (2002); Ang et al.(2004) friends from similar country of origin

2) I feel that the mess caused by America has resulted in discomfort to my family

3) I hate American that has put my friends from similar country of origin in suffering.

4) I hate America that has put my friends from similar country of origin in more suffering.

5) I find it difficult to forgive America for what they did for our intervention so far.

6) America has made me feel more insecure at this time.

7) America has made us worrying about our future.

Consumer Ethnocentrism

1) The products made in Indonesia are the first, last and leading.

2) Purchasing foreign products is not Indonesian

3) It is not the right thing to purchase foreign products as it can lead to Indonesian to experience unemployment

4) We should purchase product that is produced in Indonesia instead letting other countries get rich by oppressing us

5) Indonesian consumers who buy foreign-made products are responsible for the placement of a countryman (Indonesia) out of the job

Purchase Intention of Foreigns Product

1) Maybe, I will buy some products from America

2) Maybe, I will give a recommendation to my friends and relatives to buy some products from America

Shimp and Sharma (1987); Klein et al., (1998); Ramadania et al. (2015)
Edell and Staelin (1983);

Mackenzie et al., (1986); Liu et al., (2006)

Result and Discussion

Table 2 shows the respondent characteristics which consist of gender, age, education, occupation and income.

Table 2. Respondent Characteristics

\begin{tabular}{lll}
\hline Information & Total $(\mathrm{N}=225)$ & $\%$ \\
Gender & 120 & 53.3 \\
Male & 105 & 46.7 \\
Female & 28 & \\
\hline Age & 110 & 12.4 \\
17-20 years old & 46 & 48.9 \\
21-30 years old & 33 & 20.4 \\
31-40 years old & 8 & 14.7 \\
41-50 years old & & 3.6 \\
51+ years old & 1 & \\
\hline Education & 9 & 0.4 \\
Elementary School & 101 & 4.0 \\
Junior High School & 28 & 44.9 \\
Senior High School & 81 & 12.4 \\
DIPLOMA & 5 & 36.0 \\
S-1 (Bachelor) & & 2.2 \\
S-2 (Master) & 1 & \\
\hline Occupation & 31 & .4 \\
No Answer & 98 & 43.8 \\
Civil Servant & & \\
Private Employee & & \\
\hline
\end{tabular}




\begin{tabular}{lll}
\hline Labor & 5 & 2.2 \\
Seller/Trader & 26 & 11.6 \\
Unemployed & 21 & 9.3 \\
College Student & 30 & 13.3 \\
Others & 13 & 5.8 \\
\hline Income & & \\
No Income & 3 & 1.3 \\
< Rp. 1.000.000.- & 52 & 23.1 \\
1 million - 3 million & 92 & 40.9 \\
3 million - 5 million & 46 & 20.4 \\
5 million - 10 million & 22 & 9.8 \\
10 million - 20 million & 9 & 4.0 \\
million -50 million & 0 & 0 \\
$>50$ million & 1 & 0.4 \\
\hline
\end{tabular}

Table 3. Loading Factor

\begin{tabular}{llccc}
\hline Indicator of Constructs & Loading Factor & S.E & C.R & P \\
\hline National Stable Animosity & & & & \\
NSA1A & 0.701 & & & \\
NSA2A & 0.885 & 0.123 & 10.203 & $* * *$ \\
NSA3A & 0.780 & 0.116 & 10.231 & $* * *$ \\
\hline Personal Stable Animosity & & & & \\
PSA1A & 0.931 & & & \\
PSA2A & 0.885 & 0.060 & 15.401 & $* * *$ \\
PSA3A & 0.675 & 0.054 & 11.400 & $* * *$ \\
\hline National Situational Animosity & & & & \\
NSTSA1A & 0.763 & & & \\
NSTSA2A & 0.825 & 0.133 & 7.989 & $* * *$ \\
NSTSA3A & 0.581 & 0.112 & 7.547 & $* * *$ \\
\hline Personal Situational Animosity & & & & \\
PSTSA1A & 0.788 & & & \\
PSTSA2A & 0.839 & 0.075 & 14.562 & $* * *$ \\
PSTSA3A & 0.932 & 0.081 & 16.492 & $* * *$ \\
PSTSA4A & 0.921 & 0.083 & 16.166 & $* * * *$ \\
PSTSA5A & 0.832 & 0.080 & 13.988 & $* * *$ \\
PSTSA6A & 0.799 & 0.081 & 13.204 & $* * *$ \\
PSTSA7A & 0.760 & 0.090 & 12.378 & $* * *$ \\
\hline Consumer Ethnocenrism & & & & \\
CE1 & 0.671 & & & \\
CE2 & 0.751 & 0.129 & 9.380 & $* * *$ \\
CE3 & 0.779 & 0.127 & 9.447 & $* * *$ \\
CE4 & 0.754 & 0.117 & 9.572 & $* * *$ \\
CE5 & 0.672 & 0.110 & 8.459 & $* * *$ \\
\hline Intention to Purchase & & & & \\
Intention 1 & Unidentified & & & \\
Intention 2 & Unidentified & & & \\
\hline & all & & & \\
\hline
\end{tabular}

The Loading Factor for the indicator of all constructs was above 0.5 (the lowest value is 0.581 ) and was statistically significant at the level of $5 \%$ (Table 3 ). Thus, it can be said that the indicators that measure the constructs have a good convergent validity (Anderson and Gerbing. 1988). The construct reliability test using construct reliability and Cronbach's a had a value above 0.70 (Table 4). It shows that all constructs had a high reliability value. (Hair. 1998).

Table 4. Reliability Test

\begin{tabular}{llll}
\hline Construct & Items & Construct Reliability & Cronbach's a \\
\hline National Stable Animosity & 3 & 0.834 & 0.829 \\
\hline Personal Stable Animosity & 3 & 0.874 & 0.867 \\
\hline National Situational Animosity & 3 & 0.771 & 0.758 \\
\hline Personal Situational Animosity & 7 & 0.944 & 0.945 \\
\hline \hline \multirow{2}{*}{ www.jbrmr.com A Journal of the Academy of Business and Retail Management (ABRM) } & \multirow{2}{*}{202}
\end{tabular}




\begin{tabular}{llll}
\hline Consumer Ethnocentrism & 5 & 0.848 & 0.836 \\
\hline Intention to purchase of Foreign Product & 2 & - & 0.836 \\
\hline
\end{tabular}

Tabel 5. Goodness of Fit Index

\begin{tabular}{lll}
\hline Goodness of Fit Index & Cut-off Value & Value \\
\hline$X^{2}$ & Expected to be low & 420.514 \\
DF (Prob) & & 215 \\
$X^{2}$ - Significance Probability & $\geq 0.05$ & 0.000 \\
Relative X² (CMIN/DF) & $\leq 2.00$ & 1.956 \\
TLI & $\geq 0.90$ & 0.932 \\
CFI & $\geq 0.90$ & 0.942 \\
IFI & $\geq 0.90$ & 0.943 \\
RMSEA & $\leq 0.08$ & 0.065 \\
PNFI & $>0.50$ & 0.756 \\
PCFI & $>0.50$ & 0.800 \\
\hline
\end{tabular}

Note: X2: Chi-square statistic. RMSEA: Root-Mean-Square-Error of Approximation. CFI: Comparative Fit Index. IFI: Incremental Fit Index. TLI:Tucker Lewis Index PNFI: Parsimonious Normal Fit Index (PNFI). $\mathrm{P}<0.05$.

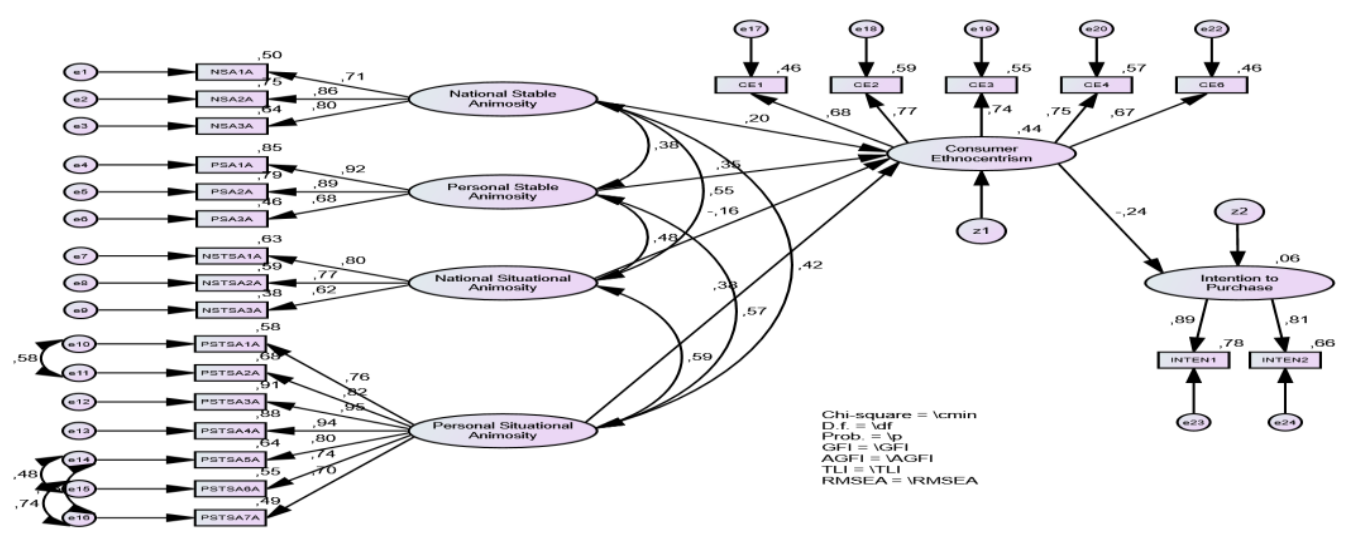

Figure 2. Full Model Structural Test

The result of full model structural test after the modification still shows a high $\mathrm{X}^{2}$ value $\left(X^{2}=420.514 . \mathrm{df}=215\right.$. Prob=0.000). The model has not met the fit model criteria. There is a need to see other indicators of conformity. The value of CMIN/DF $=1.956(\mathrm{CMIN} / \mathrm{DF}<2)$ has met the criteria. The values of TLI $=0.932, \mathrm{CFI}=0.942 \& \mathrm{IFI}=0.943$ are all above 0.90 and have met the criteria. Similarly, the value of RMSEA $=0.065(\leq 0.08)$. PNFI $=0.756(>0.50)$ and PCFI $=0.80(>0.50)$ have also met the fit model criteria. Thus. it can be said that the structural model is good enough for further testing hypothesis.

Table 6. Hypothesis Testing

\begin{tabular}{|c|c|c|c|c|c|}
\hline Path & $\begin{array}{l}\text { Std } \\
\text { Estimate }(\beta)\end{array}$ & S.E. & C.R. & $\mathrm{P}$ & Hypothesis \\
\hline National Stable Animosity $\rightarrow \mathrm{CE}$ & 0.197 & .085 & 2.292 & .022 & H1. Accepted \\
\hline Personal Stable Animosity $\rightarrow \mathrm{CE}$ & 0.348 & .068 & 4.108 & $* * *$ & H2. Accepted \\
\hline National Situational Animosity $\rightarrow \mathrm{CE}$ & -0.157 & .089 & -1.528 & .127 & H3. Rejected \\
\hline Personal Situational Animosity $\rightarrow \mathrm{CE}$ & 0.381 & .087 & 4.029 & $* * *$ & H4. Accepted \\
\hline Consumer Ethnocentrism $\rightarrow$ Intention & -0.240 & .092 & -2.930 & .003 & H5. Accepted \\
\hline
\end{tabular}

All hypotheses tested the relationship between variables (see Figure 2). The results of hypothesis testing showed that National stable animosity has a positive effect on CE by 0.197 and it is significant (Alpha 5\%), thus Hypothesis1 is accepted. Personal stable animosity is also proven to be the predictor of CE with a positive effect of 0.348 and it is significant (Alpha 0.000). Thus, hypothesis2 is accepted. The national situational animosity construct in this study is not proven to have an effect on CE. Therefore, hypothesis 3 is rejected. The effect of situational animosity on CE is 0.381 and it is significant (Alpha 0.000 ), thus hypothesis 4 is also accepted. CE has a negative effect on purchase intention of foreign products by -0.240 and it is significant (Alpha 0.05). Thus, Hypothesis 5 is also accepted. This study had 
proven that animosity as the antecedent of $\mathrm{CE}$, particularly the national stable animosity, personal stable animosity and personal situational animosity. This study had supported and reinforced the findings of Nisjenn and Douglas (2004), Torres and Gutieres (2007) and Jimenez and Martin (2010) that animosity as a strong predictor of CE. The higher the level of consumer animosity towards foreign people and foreign countries, the higher the consumer love towards domestic products. This finding has supported the suggestion from Shankarmahesh (2006) to examine animosity as the predictor of CE. As expressed by Ang et al. (2004), when animosity is activated it will simultaneously bring up a latent consumer ethnocentrism. This study also showed that the concept of animosity proposed by Jung et al., (2002) and Ang et al., (2004) that distinguished animosity into personal animosity vs national animosity and stable animosity vs situational animosity is a good measurement in the development of the concept of animosity. This is another alternative to the animosity measurement conducted by Klein (1998 \& 1999) that distinguished animosity based on war animosity and economic animosity, because animosity is not only caused by war and economic factors, but also by political issues, cultural differences and other factors. The study conducted by Ang et al., (2004) suggested that the severe suffering experienced by a country causes consumers to be more ethnocentric.

Unfortunately, this study could not prove the effect of national situational animosty on CE. It was due to the animosity towards foreign countries that is situational is not permanent. As expressed by Ang et al., (2004) that this situational animosity arises temporarily caused by certain circumstances. So that, consumers do not feel a deep animosity and they find it is easy to forgive mistakes made by foreign people/countries. As the findings by Ang et al., (2004) that although the animosity of Indonesian people is very high towards Japan, but they find it is easy to forgive the mistakes made by Japan to Indonesia. This study had also proven that $\mathrm{CE}$ has a negative effect on the purchase intention of foreign products. Consumers love in their own country tends to direct their attitude to love domestic products and rejects foreign products. The results of this study indicated that CE can predict purchase intention and final purchase of the consumers. The findings of this study supported the study conducted by Rose et al., (2009), Nakos and Hadijimitiou (2007), Torres and Gutieres (2007) and Nguyen et al., (2008).

\section{Managerial Implications}

The findings of this study had an implication for the importance of animosity and CE constructs for both marketing managers and academicians. This study showed that animosity is a strong predictor of CE. Therefore, international marketers should be more sensitive to animosity issue in a country because it can increase CE. Ultimately, this attitude will lead to the rejection of foreign products and the shift of consumers to domestic products. Political, religious and cultural issues should be examined more deeply, both the stable and situational as well as national and personal issues. Marketers can incorporate the global branding into local branding. For academicians, this research had given an implication for the expansion of the measurement dimension of animosity, that not only looks at the factors of war and economic animosity, but also to be able to develop the measurement dimension of animosity as proposed by Ang et al., (2004) and Jung et al., (2002), which was based on the personal vs national animosity, and situational vs stable animosity.

\section{Limitations and future research}

This study could not prove the national situational effect on CE. There is a need of future study in different contexts and settings. This study has some limitations that it only tested on supplement products from America. Future researchers can examine animosity and CE in predicting the purchase intention of foreign products in other product categories and from different COOs. The future study can examine the antecedent of animosity.

\section{References}

Al Ganideh Saeb Farhan. (2017). Being Arab and American: Understanding Ethnocentric Tendencies for Arab American Consumers. Journal of Global Marketing. 0(0). 1-15.

Anderson James C. and David W. Gerbing. (1988). Structural Equation Modeling in Practice: A Review and Recommended Two-Step Approach. Psychological Bulletin. 103(3).411-423.American Psychological Association.Inc.

Amine Lyn Suzanne. (2008). Country of origin. Animosity and consumer response: Marketing implications of antiAmericanism and Francophobia. International Business Review. 17(1).402-422. 
Ang. Swee Hoon. (2004). Animosity towards economic giants: what the little guy thinks. Journal of Consumer Marketing. 21(3). 190-207.

Apil. Ali Riza. (2006). Foreign Product Perceptions and Country of Origin Analysis across Black Sea; Studies on Azerbaijan. Bulgaria. Georgia. Russia and Turkey. IBSU International Refereed Multi-diciplinary Scientific Journal. 1(2). 22-38.

Bahaee. Mahmood and Michael J. Pisani. (2009a). Iranian consumer animosity and U.S. products: A witch's brew or elixir ?. International Business Review. 18(1).199-210.

Bahaee. Mahmood and Michael J. Pisani. (2009b). Are Iranian consumers poised to "buy American" in a hostile bilateral environment? Business Horizons. 52(1). 223-232.

Bahaee. Mahmood and Michael J. Pisani. (2009c). The Use of the Consumer Ethnocentrism and Consumer Animosity Scales in Iran: A Research Note. Thunderbird International Business Review. 51(2) March/ April. Published online in Wiley InterScience.

Balabanis, G., Mueller, R. and Melewar, T.C. (2002). The human values' lenses of country of origin images. International Marketing Review. 19(6). 582-610.

Edwards Ron. Anne-Marie Gut. Felix Mavondo. (2007). Buyer animosity in business markets: Evidence from the French nuclear test. Industrial Marketing Management. 36(1). 483-492.

Ferrin Pilar Fernández. Belén Bande-Vilela. Jill Gabrielle Klein. M. Luisa del Río-Araújo. (2015). Consumer animosity: antecedents and consequences. International Journal of Emerging Markets. 10(1).73-88.

Giang Nguyen ThiHuong and Nguyen Dinh Khoi. (2015). The Impact of Consumer Animosity and Consumer Ethnocentrism on Intention to Purchase Foreign Products: The Case of Chinese Branded Household Appliances in Vietnam Market. Journal of Economics and Behavioral Studies.7(4). 22-36.

Gongxing, Guo and Quan Lin. (2017). Consumers Become More or Less Ethnocentric? A Meta-Analysis on Level of Consumer Ethnocentrism. International Journal of Business and Management. 12(2).

Hair, Joseph. F. (1998). Multivariate Data Analysis. New York: Macmillan. Inc.

Haithem, Zourrig, Chebat Jean Charles, Toffoli. Roy and Alexandra Medina-Borja. (2010). In-Group Favoritism" and "Out-Group Prejudice"? Customers' Copings with Interpersonal Conflicts in Intra and Inter-Cultural Service Encounters. Proceedings ASBBS Annual Conference: Las Vegas. 17(1).

Hamin and Greg Elliott. (2006). A less-developed country perspective of consumer ethnocentrism and "country of origin" effect: Indonesian evidence. Asia Pacific Journal of Marketing. 18(2). 79-92.

Hsu. Jane Lu and Han-Peng Nien. (2008). Who are ethnocentric? Examining consumer ethnocentrism in Chinese societies. Journal of Consumer Behavior. 7(1). 436-447.

Huang Yu-An. Ian Phau and Chad Lin. (2010). Consumer animosity. economic hardship. and normative influence: How do they affect consumers' purchase intention? European Journal of Marketing. 44(7). 909-937.

Business Industries. (2011). The Greatest Imports of Our Traditional Medicines Turned from America. Retrieve from http:/ /industri.bisnis.com/. Access on Sunday. 30/10/2011 17:55 PM.

Javalgi, Rajshekhar G., Virginie Pioche Khare, Andrew C. Gross and Robert F. Scherer, (2005). An Application of the Consumer ethnocentrism model to French Consumer. International Business Review, 14(1). 325-344.

Jimenez, Nadia Huitzilin and Sonia San Martin. (2010). The Role of Country-of-origin. ethnocentrism and animosity in promoting consumer trust. The moderating role of familiarity. International Business Review. 19(1). 34-45.

Jung K, Ang, S.H. Leong, S.M. Tan. S.J. Pornpitakpan. C. and Kau. A.K. (2002). A Typology of animosity and its crossnational validation. Journal of Cross-Cultural Psychology. 33(6). 529-539.

Erdener, Kaynak and Ali Kara. (2002). Consumer perceptions of foreign products: An analysis of product-country images and ethnocentrism. European Journal of Marketing. 36(7). 928 - 949.

Klein, J. G. (2002). Us versus them. or us versus everyone? Delineating consumer aversion to foreign goods. Journal of International Business Studies. 33(2). 345-63.

Klein, J .G. and Ettensen. R. (1999). Consumer animosity and consumer ethnocentrism: an analysis of unique antecedents". Journal of International Consumer Marketing. 11(4). 5-24.

Klein, J. G. Ettensen. R. and Morris. M.D. (1998). The animosity model of foreign product purchase: an empirical test in the People's Republic of China. Journal of Marketing. 62(1). 89-100.

Kwak, Hyokkjin, Anupam Jaju and Trina Larsen. (2006). Consumer Ethnocentrism Offline and Online: The Mediating Role of Marketing Efforts and Personality Traits in the United States, South Korea, and India. Journal of the Academy of Marketing Science. 34(3). 367-385.

Lee Richard and Kyung Tae Lee. (2013). The longitudinal effects of a two-dimensional consumer animosity. Journal of Consumer Marketing. 30(3).273-282.

Liu Fang, Jamie Murphy, Jianyao Li and Xiangping Liu. (2006). English and Chinese? The Role of Consumer Ethnocentrism and Country of Origin in Chinese Attitudes towards Store Signs. Australasian Marketing Journal. 14(2). 66-78. 
Maher, Amro A, Paul Clark and Ahmed Maher. (2010). International consumer admiration and the persistence of animosity. Journal of Consumer Marketing. 27(5). 414-424.

Moon B. J. and S. C. Jain. (2002). Consumer processing of foreign advertisements: roles of country-of-origin perceptions. consumer ethnocentrism and country attitude. International Business Review 11(1). 117-138.

Nijssen Edwin J and Susan P. Douglas. (2004). Examining the animosity model in a country with a high level of foreign trade. International Journal of Research in Marketing. 21(1). 23-38.

Nguyen, Tho D. Trang, T.M. Nguyen, and Nigel J. Barrett. (2008). Consumer ethnocentrism. cultural sensitivity. and intention to purchase local products: Evidence from Vietnam. Journal of Consumer Behavior. 7(1).88-100.

Nakos, George E. and Yannis A. Hajidimitriou. (2007). The Impact of National Animosity on Consumer Purchases: The Modifying Factor of Personal Characteristics. Journal of International Consumer Marketing. 19(3). 53-72.

Ma. Jun, Sijun Wang, and Wei Hao. (2012). Does cultural similarity matter? Extending the animosity model from a new perspective. Journal of Consumer Marketing. 29(5).319-332.

Ramadania, Sri Gunawan and Jamaliah. (2013). Country of Origin Effect and Animosity on the Attitude and Purchase Intention of Foreign Products. ASEAN Marketing Journal. 5(1). 59-68.

Ramadania, Sri Gunawan and M. Rustam, (2015). Cultural Similarity, Consumer Ethnocentrims and Product Necessity in Evaluation of Malaysian Products: Indonesian Consumer Perspective. Procedia Social and Behavioral Sciences. 211. 533-540.

Ranjbarian Bahram, Morteza Rojuee, and Abbas Mirzaei. (2010). Consumer Ethnocentrism and Buying Intention. European Journal of Social Sciences. 8(3): 371-386.

Riefler Petra and Adamantios Diamantopoulos. (2007). Consumer animosity: a literature review and a consideration of its measurement. International Marketing Review. 24(1). 87-119.

Russell Dale W. and Cristel Antonia Russell. (2006). Explicit and implicit catalysts of consumer resistance: The effects of animosity. cultural salience and country-of-origin on subsequent choice. International Journal of Research in Marketing. 23(2). 321-331.

Ruyter Ko de, Marcel van Birgelen, and Martin Wetzels. (1998). Consumer ethnocentrism in international services marketing. International Business Review. 7. 185-202.

Rose Mei, Gregory M. Rose, and Aviv Shoham. (2009). The Impact of consumer animosity on attitudes towards foreign goods: a study of Jewish and Arab Israelis. Journal of Consumer Marketing. 26(5). 330-339.

Shimp, Terence A and Subhash Sharma. (1987). Consumer Ethnocentrism: Construction and Validation of the CESCALE. Journal of Marketing Research. Vol.XXIV (August). 280-289.

Sharma, S., Shrimp, T. A., and Shin. J. (1995). Consumer Ethnocentrism: A test of Antecedents and Moderators. Journal of the Academy of Marketing Science. 23(1). 26-37.

Shankarmahesh, Mahesh N. (2006). Consumer ethnocentrism: an integrative review of its antecedents and consequences. International Marketing Review. 23(2). 146-172.

Shin, Mincheol Shin. (2001). The Animosity Model of Foreign Product Purchase. Journal of Empirical Generalisations in Marketing Science. 6(1).1-14

Torres, Nadia Huizilin Jimenez and Sonia San Martin Gutierrez. (2007). The purchase of foreign products: The role of firm's country-of-origin reputation. Consumer Ethnocentrism. animosity and trust. Documento de trabajo. 13. Oktober.

Watson, John J and Katrina Wright. (2000). Consumer ethnocentrism and attitudes toward domestic and foreign products. European Journal of Marketing. 34(9). 1149-1166.

Yagci. Mehmet I. (2001). Evaluating the Effects of Country-of-Origin and Consumer Ethnocentrism: A Case of a Transplant Product. Journal of International Consumer Marketing. 13(3). 71-87.

Shah Khairul and Anuar Mohammad. (2012). The Effect of Consumer Animosity. Consumer Ethnocentrism And Patriotism On Purchase Willingness: A Study In Malaysia. International Journal of Arts E Sciences. 5(1). 27-35 .

Seidenfuss Kai-Uwe, Yunus Kathawala and Keith Dinnie. (2013). Regional and country ethnocentrism: broadening ASEAN origin perspectives. Asia Pacific Journal of Marketing and Logistics. 25(2). 102-111.

Sutikno, B and J. M. S. Cheng (2011). Towards Consumer Ethnocentrism and Animosity. Indonesia. International Journal Management Business. (1). 15-18.

Spillan John E and Talha Harcar (2012). Chilean Consumers Ethnocentrism Factors and Their Perception Regarding Foreign Countries Products. Journal of Marketing Development and Competitiveness. 6(1). 114-128. 